\title{
Population density and genetic structure of the giant clams Tridacna crocea and T. squamosa on Singapore's reefs
}

\author{
Mei Lin Neo ${ }^{1,2}$, Peter A. Todd ${ }^{1, *}$ \\ ${ }^{1}$ Experimental Marine Ecology Laboratory, Department of Biological Sciences, National University of Singapore, \\ 14 Science Drive 4, Blk S2 \#02-02, Singapore 117543 \\ ${ }^{2}$ Tropical Marine Science Institute, National University of Singapore, 14 Kent Ridge Road, \#02-01, Singapore 117543
}

\begin{abstract}
Giant clams in Singapore have been subjected to anthropogenic impacts such as fishing, coastal development and sediment pollution for decades, making their study a priority for local reef management. Between September 2009 and August 2010, 29 reefs among Singapore's Southern Islands were surveyed (total area $=87515 \mathrm{~m}^{2}$ ). Both intertidal and subtidal zones were included, i.e. from shore to the edge of the upper reef slope (depths $=1$ to $6 \mathrm{~m}$ ). A total of 59 clams (but no juveniles) were found, resulting in a contemporary density of 0.067 per $100 \mathrm{~m}^{2}$. Only 2 species, Tridacna crocea and T. squamosa, were encountered, compared to the 4 species recorded historically. The genetic relatedness among individuals from these 2 species was examined using cytochrome $c$ oxidase subunit I (COI). Higher levels of polymorphism and genetic diversity were observed among $T$. crocea; both were less pronounced in the $T$. squamosa population, where a single haplotype was present in half of the individuals. The reef conditions in Singapore, especially the lack of suitable substrate and high turbidity, create a poor environment for giant clam reproduction and recruitment. It appears to be low mortality among mature clams that maintains the present population, but with the adults exposed to ongoing stressors, Singapore's entire giant clam stock is endangered.
\end{abstract}

KEY WORDS: Giant clam $\cdot$ Sediment $\cdot$ Distribution $\cdot$ Survey $\cdot$ Restocking $\cdot$ Population genetics

\section{INTRODUCTION}

Coral reefs and their associated fauna are under intense anthropogenic pressure, especially from overexploitation and poor management of coastal resources (Wilkinson 2008). Intervention efforts, such as the formation of marine protected areas (MPAs) (Carleton Ray 1999, Palumbi 2001) and integrated coastal management schemes (Castilla 2000, Arkema et al. 2006), can ameliorate some of these impacts. One of the major challenges for such schemes, and for coral reef conservation in general, is accounting for the bipartite life history characteristic of many reef taxa-where the adult is either sedentary or possesses a limited home range, while the larvae are dispersed by currents (Scheltema 1988). In order to effectively protect marine biodiversity, Carpenter et al. (2011) highlighted the need to manage MPAs on a larger spatial scale, such as including nearby reefs, since most species' ranges span over large distances. Data on connectivity among coral reefs, however, are often deficient or absent. Population genetics have provided the opportunity to investigate a variety of ecological interactions, including the linkages between spatially separated groups of conspecifics (Grosberg \& Cunningham 2001, Hedgecock et al. 2007). Their genetic structures can provide information on larval dispersal and distribution patterns 
(Hedgecock 1986), providing insights on the probable sources and sinks of pelagic larvae (JuinioMeñez et al. 2003, Selkoe et al. 2008).

Giant clams (Tridacnidae) are conspicuous bivalves that live in close association with coral reefs throughout the Indo-Pacific (Lucas 1988). They have a well-developed planktonic phase of $\sim 9 \mathrm{~d}$ (Lucas 1988) and therefore possess substantial dispersal potential, which may explain their widespread distribution (Benzie \& Williams 1992a, Othman et al. 2010). Even though these simultaneous hermaphrodites are highly fecund, releasing up to millions of gametes at each spawning (Lucas 1988), reproduction is sporadic (Solis 1987, Tan \& Yasin 1998) and natural recruitment of juveniles is often very low (Gomez et al. 2000). Allozyme variation studies (e.g. Laurent et al. 2002, Juinio-Meñez et al. 2003) and, more recently, mitochondrial cytochrome $c$ oxidase subunit I (COI) studies (e.g. DeBoer et al. 2008, Kochzius \& Nuryanto 2008), have provided information on the possible gene flow/larval dispersal routes within and among various Indo-Pacific giant clam populations that can either be explained by ocean current patterns (Benzie \& Williams 1992a, Macaranas et al. 1992) or geographic isolation (Benzie \& Williams 1992b). Nothing is known, however, about the extent of larval dispersal or diversity of genetic material among the giant clams on Singapore's reefs.

During the mid-20th century, 4 species of tridacnids were reported in Singapore: Tridacna crocea Lamarck, T. maxima (Röding), T. squamosa Lamarck and Hippopus hippopus (Linnaeus) (Rosewater 1965). Since the early 1960s, however, local giant clam numbers have been severely depleted due to overexploitation for food (Harrison \& Tham 1973, Dawson \& Philipson 1989) and habitat degradation (Courtois de Vicose \& Chou 1999) leading to a density of just 0.24 per $100 \mathrm{~m}^{2}$ (Guest et al. 2008). Only 3 species were found: T. crocea, T. maxima and $T$. squamosa; $H$. hippopus was not sighted in the $9670 \mathrm{~m}^{2}$ area censused. Furthermore, no juveniles of any clam species were observed, indicating a lack of natural recruitment (Guest et al. 2008).

Knowledge on the spatial distribution of genetic variation within a species is an important tool for the management of marine resources (Palumbi 2003, Carpenter et al. 2011). To forestall the decline of giant clam numbers, it is necessary to gather information on the current population status and its genetic structure. The 2003 survey by Guest et al. (2008) was limited to 7 reef sites and no genetic work was undertaken. Here we present results from a much larger survey conducted to definitively quan- tify the distribution and abundance of giant clams among Singapore's Southern Islands. In addition, genetic relatedness among individuals from 2 species, Tridacna crocea and T. squamosa, was examined using COI - a commonly used gene marker for studies on bivalve population genetics (e.g. Luttikhuizen et al. 2003, Nuryanto et al. 2007).

\section{MATERIALS AND METHODS}

\section{Study area}

Singapore $\left(1^{\circ} 22^{\prime} \mathrm{N}, 103^{\circ} 48^{\prime} \mathrm{E}\right)$ is a small island nation (land area $=710.2 \mathrm{~km}^{2}$ ) situated at the southern tip of Peninsular Malaysia. The climate is equatorial, with high temperatures and rainfall throughout the year, but there exists a relatively wet northeast monsoon (December to February) and a relatively dry southwest monsoon (June to August) (Thia-Eng et al. 2000). Coral reefs are either patch or fringing, and generally distributed around the islands to the south of the mainland (Chou 1999), known locally as the Southern Islands. Singapore's reefs were previously described as having wide reef flats and steep reef slopes but many reef flat areas, for example Pulau Sudong (Pulau = island, abbreviated to P.) and P. Hantu, have been reclaimed, i.e. filled in to create new land area (Chou 1999). The remaining reefs continue to experience direct sediment impacts from coastal construction and dredging of shipping lanes (Chou 2008), while associated turbidity has severely reduced light penetration (Low \& Chou 1994, Dikou \& van Woesik 2006).

\section{Survey method and tissue sampling}

Between September 2009 and August 2010, 29 Southern Island reefs were surveyed. Sites represent all of Singapore's reef types: patch versus fringing, restricted versus accessible, upstream versus downstream, as well as reefs experiencing various levels of human impact. Both intertidal and subtidal zones, i.e. from shore to the edge of the upper reef slope (depths of 1 to $6 \mathrm{~m}$ below mean sea level), were included within the area surveyed. To calculate giant clam density, $6 \mathrm{~m}$ wide belt transects, covering almost the entire length of the target reefs, were used for SCUBA searches, while intertidal surveys were conducted by censuring large portions of the reef flat, using quadrats of $10 \times 10$ to $20 \times 20 \mathrm{~m}^{2}$. All clams found were identified to species level and their sizes, 
and GPS positions when possible, recorded. A labelled stainless steel stake was also hammered into the nearby substrate for future reference. Areas searched at each site varied from 100 to $7000 \mathrm{~m}^{2}$, but all were surveyed with equal unit effort (search time $\mathrm{m}^{-2}$ ). Biopsies of mantle tissue were taken whenever possible (i.e. when the clams did not close their valves completely) and preserved in $96 \%$ ethanol.

\section{DNA extraction, amplification and sequencing}

Tissue samples for DNA extraction were subsampled, air-dried, ground, and incubated for $24 \mathrm{~h}$ at $55^{\circ} \mathrm{C}$ in CTAB buffer with $20 \mu \mathrm{g} \mathrm{ml}^{-1}$ proteinase $\mathrm{K}$. The mixture was agitated with $500 \mu \mathrm{l}$ phenol/chloroform mixture for 1 min before extraction of aqueous supernatant. This procedure was repeated once before an equal volume of absolute ethanol was added and stored at $-80^{\circ} \mathrm{C}$ overnight to elucidate the DNA pellet. The pellet was subsequently washed with $70 \%$ ethanol. RNase-free water was used to dissolve the DNA before storage at $-80^{\circ} \mathrm{C}$.

Approximately 500 base pair (bp) of the mitochondrial COI gene was amplified via polymerase chain reaction (PCR) using Tridacna-specific primers (DeBoer et al. 2008, Kochzius \& Nuryanto 2008). PCR was carried out in a total volume of $23 \mu \mathrm{l}$, and contained $2 \mu$ l DNA template, Thai TAQ buffer, $10 \mathrm{mM}$ dNTPs, BSA additive, $10 \mu \mathrm{M}$ of each primer and $0.8 \mu \mathrm{l}$ Thai TAQ. The COI gene for T. crocea was amplified using COI-Tricro-Frwd 5-GGG TGA TAA TTC GAA CAG AA-3 and COI-Tricro-Rev 5 -TAG TTA AAG CCC CAG CTA AA-3 (Kochzius \& Nuryanto 2008), initial denaturation at $94^{\circ} \mathrm{C}$ for $3 \mathrm{~min}$, followed by 35 cycles of $94^{\circ} \mathrm{C}$ for $1 \mathrm{~min}, 52^{\circ} \mathrm{C}$ for $1.5 \mathrm{~min}$, $72^{\circ} \mathrm{C}$ for $1 \mathrm{~min}$, and a final extension of $72^{\circ} \mathrm{C}$ for $5 \mathrm{~min}$. The COI gene for $T$. squamosa was amplified using SQUA-R1 5-ATG TAT AAA CAA AAC AGG ATC-3 and SQUA-F3 5 -CAT CGT TTA GAG TAA TAA TTC G-3 (DeBoer et al. 2008), with PCR parameters of initial denaturation at $94^{\circ} \mathrm{C}$ for $15 \mathrm{~s}$, followed by 38 cycles of $94^{\circ} \mathrm{C}$ for $30 \mathrm{~s}, 50^{\circ} \mathrm{C}$ for $30 \mathrm{~s}$, $72^{\circ} \mathrm{C}$ for $45 \mathrm{~s}$, and a final extension of $72^{\circ} \mathrm{C}$ for $3 \mathrm{~min}$. PCR success was determined by means of gel electrophoresis in $1 \%$ agarose gel using $2 \mu \mathrm{l}$ of reaction mix. PCR products were purified using Bioline Quick-Clean DNA (Randoph), and each sequencing reaction volume comprised $2 \mu \mathrm{l}$ of PCR product, $0.5 \mu \mathrm{l}$ of BigDye Terminator v3.1. (Applied Biosystems), $2 \mu \mathrm{l}$ of $5 \times$ BigDye sequencing buffer, $1.75 \mu \mathrm{l}$ of sequencing primer $(10 \mu \mathrm{M})$ and topped up to $10 \mu \mathrm{l}$ with RNase-free water. The cycle sequencing profile comprised 30 cycles for $30 \mathrm{~s}$ at $95^{\circ} \mathrm{C}, 15 \mathrm{~s}$ at $50^{\circ} \mathrm{C}$ and $4 \mathrm{~min}$ at $60^{\circ} \mathrm{C}$, followed by another purification step using $5 \mu \mathrm{l}$ of Agencourt CleanSeq solution. Direct sequencing was carried out using an ABI 3130 genetic analysis sequencher (Perkin Elmer Applied Biosystems).

\section{Sequence editing}

Sequence contigs were proofread in Sequencher v4.0 (GenCodes Corporation) and subsequently aligned using ClustalX Multiple Sequence Alignment Program v2.0.12 (Thompson et al. 1997). Alignments were edited and translated to amino acids to check for stop codons in MEGA (Tamura et al. 2007) before being exported into Arlequin v3.5 (Excoffier \& Schneider 2005) and TCS v1.21 (Clement et al. 2000) for further analyses.

\section{Population genetic diversity and haplotype parsimony network}

Molecular diversity measures for both clam populations were calculated in Arlequin v3.5 (Excoffier \& Schneider 2005), including haplotype diversity and nucleotide diversity. To determine the genetic structure within each Tridacna species population, the relationships among haplotypes were inferred using parsimony networks generated by TCS v1.21 (Clement et al. 2000), and the statistical parsimony procedure followed Crandall (1994) and Templeton et al. (1992). This method estimates the maximum number of differences among haplotypes due to single substitutions with a $95 \%$ parsimony connection limit (Posada \& Crandall 2001). Outgroup weights were calculated following Castelloe \& Templeton (1994); this predicts the oldest haplotype based on the neutral coalescent theory applied to intraspecific networks (Crandall \& Templeton 1993, Posada \& Crandall 2001).

\section{Historical demography}

The null hypothesis for neutral evolution of the COI marker was tested using Tajima's $D$ test (Tajima 1989) and Fu's Fs test (Fu 1997) with 10000 permutations implemented in Arlequin v3.5. Harpending's raggedness index (HRI; Harpending 1994), based on mismatch distribution analyses, was assessed using Arlequin v3.5 (10000 permutations). The sudden 
population expansion model is rejected when a significant HRI value $(\mathrm{p}<0.05)$ is obtained (Schneider \& Excoffier 1999).

\section{RESULTS}

\section{Survey data}

Altogether 16 fringing and 13 patch reefs were surveyed. From the $87515 \mathrm{~m}^{2}$ censused (intertidal = $76470 \mathrm{~m}^{2}$; subtidal $\left.=11045 \mathrm{~m}^{2}\right) 59$ giant clams were found, comprising 2 species: Tridacna crocea $(\mathrm{n}=31$, size range $=94$ to $160 \mathrm{~mm})$ and $T$. squamosa $(\mathrm{n}=28$, 150 to $418 \mathrm{~mm}$ ) (Fig. 1, Table 1). No T. maxima or Hippopus hippopus were encountered within (or outside) the transects or quadrats. Based on information on shell sizes (e.g. Lucas 1988) none of the clams were juveniles (Fig. 1).

Densities for Tridacna crocea and T. squamosa were 0.035 and 0.032 per $100 \mathrm{~m}^{2}$ respectively. While T. crocea densities were slightly higher on the intertidal areas compared to the subtidal ones $(0.037$ versus 0.027 per $100 \mathrm{~m}^{2}$ ), the T. squamosa intertidal density was $\sim 3.2 \times$ lower than its subtidal density ( 0.025 versus 0.081 per $100 \mathrm{~m}^{2}$ ) (Table 1$)$. Our study

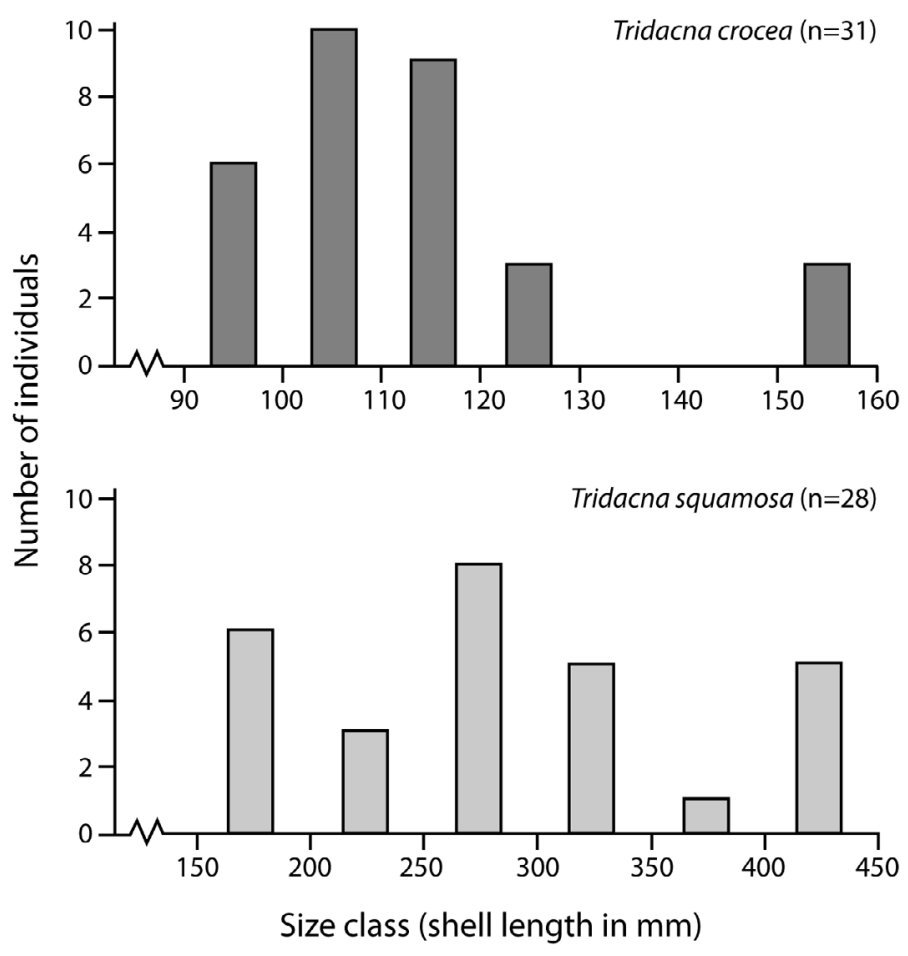

Fig. 1. Tridacna crocea and T. squamosa. Size frequency distribution on Singapore reefs included a total of 22 previously un-surveyed reefs, and clams were found at 16 of these new sites. Of the previously surveyed 7 reefs (Guest et al. 2008), one (Terumbu Bayan) has been completely reclaimed, while clams were found on all of the others.

\section{Genetics}

Sequence alignments for Tridacna crocea (27 individuals) and $T$. squamosa (20 individuals) were deposited in GenBank (accession numbers JN392020 to JN392066). Haplotype diversity was similar for both species populations, but $T$. crocea had a higher nucleotide diversity than $T$. squamosa (Table 2). From the $27 \mathrm{~T}$. crocea individuals, 10 unique COI haplotypes were obtained, with 20 polymorphic sites and 20 substitutions (18 transitions, 2 transversions) from 453-bp fragments (i.e. $4.42 \%$ variable sites). From the 20 T. squamosa individuals, 6 unique COI haplotypes were obtained, with 10 polymorphic sites and 10 substitutions (9 transitions, 1 transversion) from 471-bp fragments (i.e. $2.12 \%$ variable sites).

\section{Historical demography}

Tests of neutrality using Tajima's $D$ and Fu's FS tests were negative for both giant clam populations, but this was only significant for Tridacna squamosa, and only for Tajima's $D$. Negative values suggest that T. crocea and T. squamosa populations have undergone recent population expansions, and the mismatch distribution analysis supported this. The nonsignificant HRI values (Table 2) mean that the sudden population expansion model cannot be rejected for either population.

\section{Haplotype relationship}

Tridacna crocea showed relatively high diversity with 3 widespread haplotypes. Haplotype 3 was the most common, in 8 of 27 individuals at 6 reefs; 5 haplotypes occurred as singletons (Fig. 2). Outgroup weight calculations suggest that Haplotype 4 (outgroup weight $=0.464$ ) is the ancestral haplotype for $T$. crocea in Singapore. The T. crocea haplotypes were heterogeneously distributed throughout the reefs (Fig. 2a). Haplotype diversity within locality either differed by one mutational step (i.e. P. Salu) or occurred in separate clades (i.e. P. Senang, 
Table 1. Tridacna crocea and T. squamosa. Giant clam numbers for the 29 reefs surveyed. Sites are ranked with furthest straight-line distance to mainland at the top

\begin{tabular}{|c|c|c|c|c|}
\hline \multirow[t]{2}{*}{ Sites surveyed } & \multirow{2}{*}{$\begin{array}{l}\text { Area } \\
\left(\mathrm{m}^{2}\right)\end{array}$} & \multicolumn{3}{|c|}{ Number of giant clams } \\
\hline & & Total & T. crocea & T. squamosa \\
\hline \multicolumn{5}{|l|}{ Fringing reefs } \\
\hline Raffles Lighthouse (Pulau Satumu) & 1175 & 4 & 2 & 2 \\
\hline Pulau Biola ${ }^{b}$ & 3590 & 6 & 3 & 3 \\
\hline Pulau Senang ${ }^{b}$ & 4850 & 4 & 3 & 1 \\
\hline Pulau Pawai ${ }^{\mathrm{b}}$ & 8780 & 1 & 0 & 1 \\
\hline Pulau Sudong ${ }^{b}$ & 8080 & 1 & 0 & 1 \\
\hline Pulau Jong & 3800 & 2 & 0 & 2 \\
\hline Pulau Salu ${ }^{\text {b }}$ & 2100 & 5 & 4 & 1 \\
\hline Pulau Semakau/Sakeng ${ }^{a}$ & 6165 & 11 & 6 & 5 \\
\hline $\begin{array}{l}\text { Sisters' Islands (Pulau Subar Darat, } \\
\text { Pulau Subar Laut) }\end{array}$ & 2320 & 2 & 0 & 2 \\
\hline $\begin{array}{l}\text { St John's Island } \\
\text { (Pulau Sakijang Bendara) }\end{array}$ & 4620 & 0 & & \\
\hline $\begin{array}{l}\text { Lazarus Island } \\
\text { (Pulau Sakijang Pelepah) }\end{array}$ & 1350 & 0 & & \\
\hline Kusu Island (Pulau Tembakul) ${ }^{\mathrm{a}}$ & 1890 & 2 & 0 & 2 \\
\hline Pulau Tekukor & 3510 & 0 & & \\
\hline Pulau Hantu ${ }^{\mathrm{a}}$ & 3750 & 2 & 1 & 1 \\
\hline Labrador & 1770 & 0 & & \\
\hline \multicolumn{5}{|l|}{ Patch reefs } \\
\hline Terumbu Berkas $^{\mathrm{b}}$ & 800 & 0 & & \\
\hline Pulau Berkas ${ }^{\mathrm{b}}$ & 2300 & 1 & 0 & 1 \\
\hline Terumbu Berkas Besar ${ }^{b}$ & 3000 & 3 & 3 & 0 \\
\hline Terumbu Palat $^{\mathrm{b}}$ & 250 & 0 & & \\
\hline Beting Bemban Besar & 3750 & 2 & 0 & 2 \\
\hline Terumbu Bemban & 1000 & 0 & & \\
\hline Terumbu Salu ${ }^{\mathrm{b}}$ & 3000 & 4 & 4 & 0 \\
\hline Terumbu Semakau & 5200 & 3 & 2 & 1 \\
\hline Terumbu Raya & 1900 & 2 & 1 & 1 \\
\hline Terumbu Pempang Darat & 1590 & 1 & 1 & 0 \\
\hline Terumbu Pempang Laut & 2800 & 1 & 1 & 0 \\
\hline Terumbu Pempang Tengah & 2175 & 1 & 0 & 1 \\
\hline Cyrene (Terumbu Pandan) & 2000 & 1 & 0 & 1 \\
\hline $\begin{array}{l}\text { Total area } \\
\text { Density of clams per } 100 \mathrm{~m}^{2}\end{array}$ & 87515 & $\begin{array}{c}59 \\
0.067\end{array}$ & $\begin{array}{c}31 \\
0.035\end{array}$ & $\begin{array}{c}28 \\
0.032\end{array}$ \\
\hline $\begin{array}{l}\text { Intertidal area } \\
\text { Density of clams per } 100 \mathrm{~m}^{2}\end{array}$ & 76470 & $\begin{array}{c}47 \\
0.062\end{array}$ & $\begin{array}{c}28 \\
0.037\end{array}$ & $\begin{array}{c}19 \\
0.025\end{array}$ \\
\hline $\begin{array}{l}\text { Subtidal area } \\
\text { Density of clams per } 100 \mathrm{~m}^{2}\end{array}$ & 11045 & $\begin{array}{c}12 \\
0.109\end{array}$ & $\begin{array}{c}3 \\
0.027\end{array}$ & $\begin{array}{c}9 \\
0.081\end{array}$ \\
\hline
\end{tabular}

Terumbu Berkas Besar, P. Semakau, Terumbu Salu, Terumbu Semakau). There existed a partial genetic difference of up to 9 mutational steps $(4.9 \%$ uncorrected differences) between the ancestral Haplotype 4 with Haplotypes 5 and 6 found at Terumbu Berkas Besar and P. Senang (Fig. 2b).

In 20 Tridacna squamosa individuals sampled, Haplotype 13 (Fig. 3) predominated, being found in 10 individuals at 8 reefs. It differed from 4 other haplotypes by just 1 mutational step. Haplotypes 11, 14 and 16 represented unique individuals from their respective localities (Fig. 3a). Haplotype 16 from P. Sudong was especially distinct, differing by 7 mutational steps (2.9\% uncorrected differences) (Fig. 3b). Outgroup weight calculations obtained from TCS suggest that Haplotype 13 (outgroup weight $=0.528$ ) is the ancestral haplotype for $T$. squamosa in Singapore.

\section{DISCUSSION}

Giant clams in Singapore have been subjected to anthropogenic impacts such as fishing, coastal development and sediment pollution for decades (Dawson \& Philipson 1989, Chou 1999), making their study, and conservation, a priority for local reef management. The current survey covered an additional 22 sites, and an area 9 times greater $\left(87515 \mathrm{~m}^{2}\right)$ than the 2003 study (Guest et al. 2008). We found a total of 59 giant clams resulting in a

Table 2. Tridacna crocea and T. squamosa. Number of sequences (n), number of haplotypes ( $\mathrm{N}_{\mathrm{hp}}$ ), haplotype diversity (hp; mean $\pm \mathrm{SD})$, nucleotide diversity $(\pi ;$ mean $\pm \mathrm{SD})$, Tajima's $D$, Fu's Fs and Harpending's raggedness index $(\mathrm{HRI}) .{ }^{*} \mathrm{p}<0.05$, NS: not significant

\begin{tabular}{|c|c|c|c|c|c|c|c|}
\hline \multirow[t]{2}{*}{ Species } & \multicolumn{4}{|c|}{ - Genetic diversity } & \multicolumn{2}{|c|}{ Neutrality tests } & \multirow{2}{*}{$\begin{array}{c}\text { Mismatch distribution } \\
\text { HRI }\end{array}$} \\
\hline & $\mathrm{n}$ & $\mathrm{N}_{\mathrm{hp}}$ & $\mathrm{hp}$ & $\pi(\%)$ & Tajima's $D$ & Fu's FS & \\
\hline T. crocea & 27 & 10 & $0.86 \pm 0.041$ & $0.76 \pm 0.45$ & $-1.19^{\mathrm{NS}}$ & $-1.21^{\mathrm{NS}}$ & $0.053^{\mathrm{NS}}$ \\
\hline T. squamosa & 20 & 6 & $0.72 \pm 0.088$ & $0.31 \pm 0.22$ & $-1.68^{*}$ & $-1.14^{\mathrm{NS}}$ & $0.169^{\mathrm{NS}}$ \\
\hline
\end{tabular}


a)

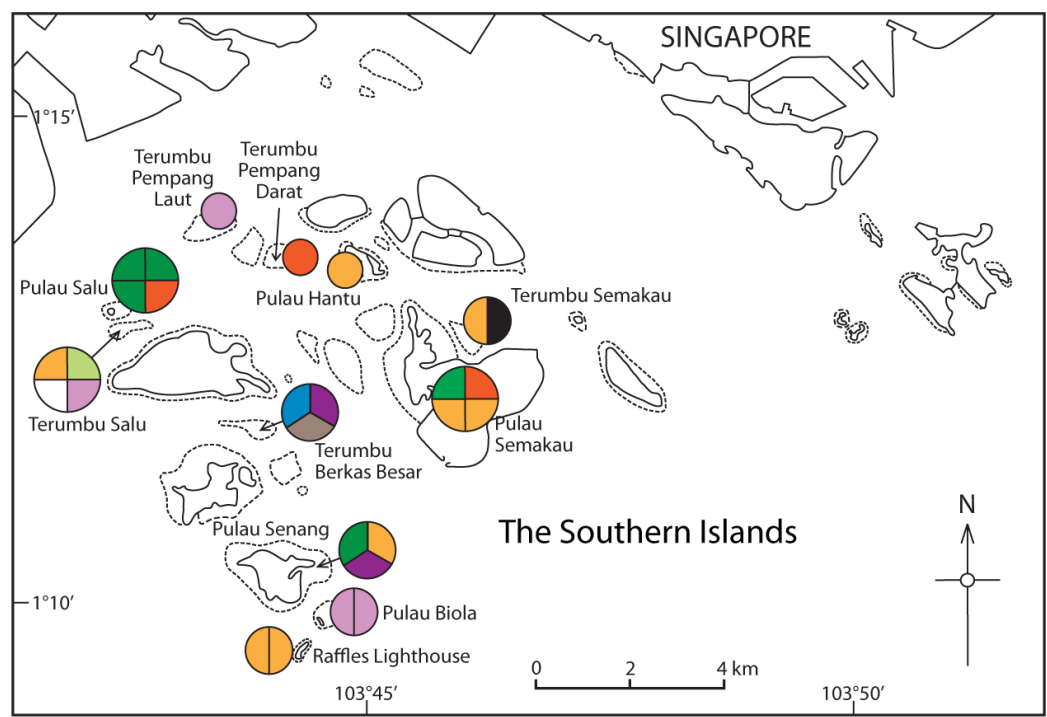

b)

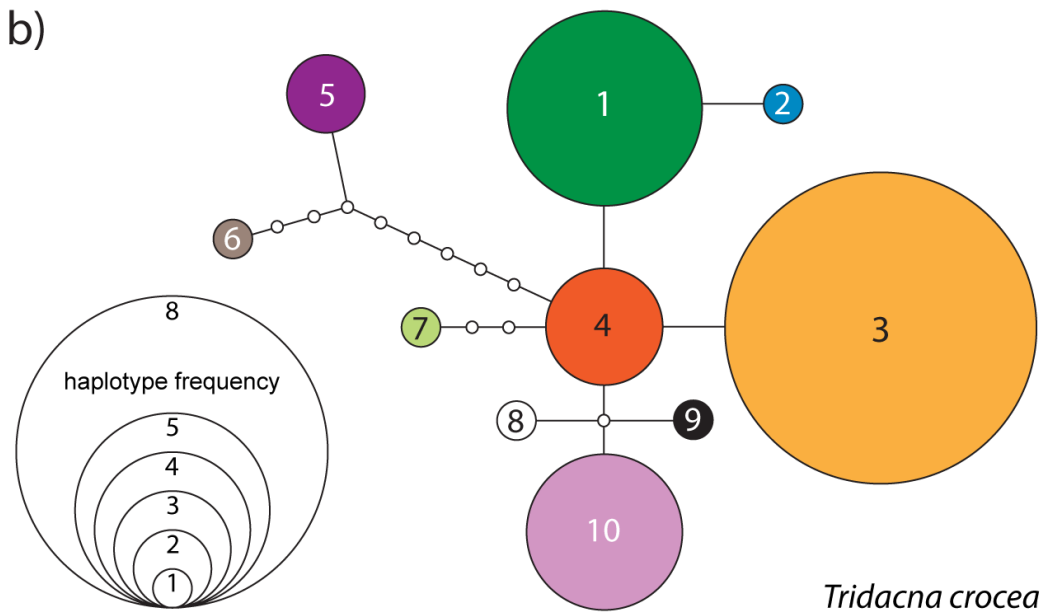

Fig. 2. Tridacna crocea. (a) Distribution of unique COI haplotypes. Individual clams represented by each section in the circle. (b) Minimum spanning network using 453-bp fragment from the COI gene. Colour-coded circles (plus reference number) = unique COI haplotype. Open circles on lines connecting haplotypes $=$ single putative mutations. Lines join all haplotypes within a $95 \%$ statistical confidence parsimony network

contemporary density of 0.067 per $100 \mathrm{~m}^{2}(\sim 4$ times lower than the 2003 figure of 0.24 per $\left.100 \mathrm{~m}^{2}\right)$; no juvenile clams were encountered. Furthermore, unlike Guest et al. (2008), we did not encounter any Tridacna maxima individuals, only $T$. crocea and $T$. squamosa. The density of $T$. crocea was quite similar in both intertidal and subtidal zones, but $T$. squamosa were more abundant in subtidal areas. The very small sample size made statistically meaningful genetic analyses impossible, but higher levels of polymorphism and genetic variation were observed within the $T$. crocea population compared to the $T$. squamosa population, where a single haplotype was present in half of the specimens.
The present survey estimates the Tridacna crocea density to be 0.035 per $100 \mathrm{~m}^{2}$. This may be a conservative figure due to this species' cryptic coloration (Todd et al. 2009) and boring behaviour that makes them hard to find (Guest et al. 2008). Nevertheless, T. crocea aggregations can reach up to $100 \mathrm{~s}$ per $\mathrm{m}^{2}$ (e.g. Chantrapornsyl et al. 1996, Tan et al. 1998), suggesting that numbers in Singapore are very low. The $T$. squamosa density in Singapore is established at 0.032 per $100 \mathrm{~m}^{2}$, lower than that in protected reefs elsewhere but higher than areas with intense exploitation (Kilada et al. 1998, Tan et al. 1998, Eliata et al. 2003). Tridacna squamosa intertidal density was 0.025 per $100 \mathrm{~m}^{2}$ whereas its subtidal abundance was 0.081 per $100 \mathrm{~m}^{2}$. For $T$. crocea, the densities in these 2 habitats were more similar (Table 1). Similar depth distributions for both species have been reported for the Johore Islands, Malaysia (Yasin \& Tan 2000) and the Red Sea (Jantzen et al. 2008), and are probably due to different light requirements, with $T$. squamosa being more tolerant to lower light and/or deeper depths (Yasin \& Tan 2000). Harvesting for food could also contribute. Giant clam gleaning during low tide is easier than extraction via snorkelling or diving (Hviding 1993) and the larger and free-living T. squamosa are less demanding to remove from the reef than the burrowing T. crocea. Exploitation of clams in Singapore has ceased but other anthropogenic inputs, especially sediment pollution from dredging of shipping lanes and nearshore construction activities (e.g. Chou 1988, Chou et al. 2004), continue to be a major problem. Sediment can deleteriously affect giant clams in numerous ways, for example, by interfering with their filter feeding (Purchon 1955), by increasing turbidity and thus reducing light reaching the photosynthetic symbiotic zooxanthellae in the clam's mantle tissues (Guest et al. 2008), and by covering reef substrates with a layer of sediment that makes it difficult for clam larvae to settle (Rogers 1990, Neo et al. 2009). 
a)

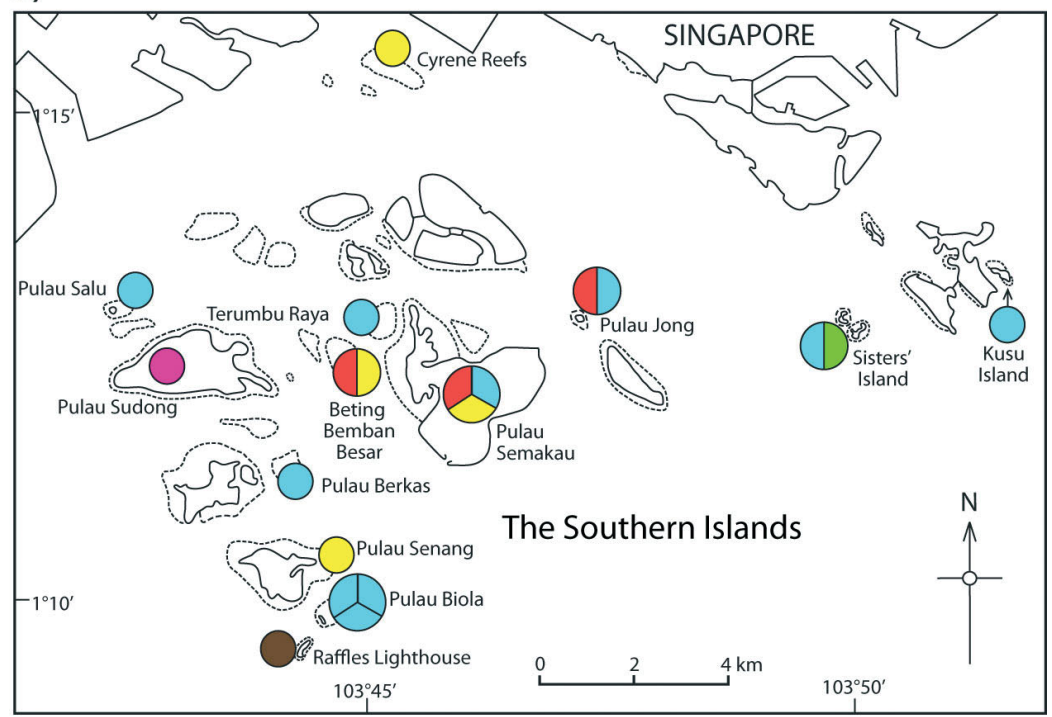

b) Tridacna squamosa

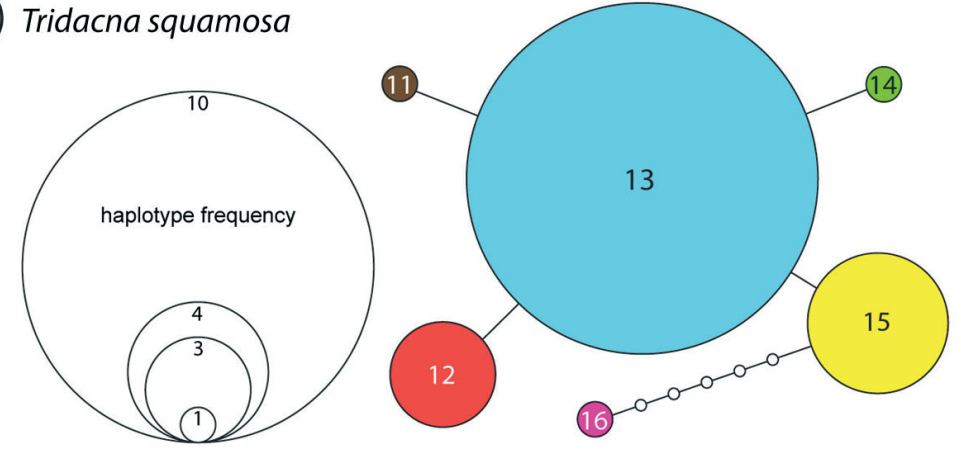

Fig. 3. Tridacna squamosa. (a) Southern Islands of Singapore showing distribution of unique COI haplotypes for T. squamosa. Individual clams represented by each section in the circle. (b) Minimum spanning network of T. squamosa using 471-bp fragment from the COI gene. See Fig. 2 for definitions

In concordance with Guest et al. (2008), we found the highest clam density $\left(0.340\right.$ per $\left.100 \mathrm{~m}^{2}\right)$ at Raffles Lighthouse, a reef generally considered Singapore's healthiest due to its high coral diversity and abundance (Huang et al. 2009) and low sedimentation levels (Todd et al. 2004). This density, however, was still considerably lower than that recorded in the 2003 survey $\left(1.290\right.$ per $\left.100 \mathrm{~m}^{2}\right)$. It should be noted that Guest et al.'s (2008) objectives and survey methods were different to ours. Their work was preliminary and the sites chosen did not represent all the reef types found in Singapore. Our study aimed to provide the definitive status of giant clams in Singapore via extensive and dedicated surveys. Guest et al. (2008) employed a SCUBA zig-zag swim search that, having no fixed boundaries, could have resulted in an underestimation of actual survey area (and therefore an overestimation of clam density). We used a combination of $6 \mathrm{~m}$ belt transects (SCUBA) and large quadrats (intertidal surveys), all measured out with nylon tapes. Our survey was scaled up to a total of 29 sites, and we were able to gain access to some rarely visited patch reefs (e.g. Terumbu Pempang Laut, Terumbu Raya) plus fringing reefs found within Live Firing Areas (e.g. P. Pawai, P. Sudong, P. Senang) managed by the Republic of Singapore Air Force that required permission to enter. Many of these more inaccessible reefs hosted giant clams. Clearly, the 2003 survey was not as comprehensive or rigorous as the one presented here, so direct comparisons of results need to be treated with a degree of caution. Nevertheless, we expect that natural mortality (albeit in an impacted environment) coupled with zero recruitment would amply explain any genuine decline since 2003.

Hippopus hippopus was last recorded in Singapore in the 1960s (Lee 1966), whereas the most recent record for Tridacna maxima, a single individual, was in 2003 (Guest et al. 2008). H. hippopus are usually found at shallow depths (Yasin \& Tan 2000), but many shallow reef flats around Singapore have been reclaimed (Chou 2008), removing a substantial portion of this species' natural habitat. T. maxima is a lithophagic species that exhibits partial burrowing (Rosewater 1965). Singapore's deteriorating coral reefs are now characterised by loose rubble (Chou 2008), which may not be able to sustain populations of mature T. maxima (shell lengths up to $300 \mathrm{~mm}$ ) that require a more consolidated substrate for stable attachment (McMichael 1974). No historical abundance data for these 2 species exist, nor any precise information on their exploitation. We can only propose that 3 factors, either individually, but more likely synergistically, have caused their extirpation from Singapore's waters: habitat loss, overexploitation, and/or the effects of sediment.

Levels of genetic diversity for both species here are similar or slightly lower than other populations within the Indo-Malay Archipelago (e.g. DeBoer et al. 2008, Kochzius \& Nuryanto 2008, Nuryanto \& Kochzius 2009). We expect that any loss of genetic variation will have coincided with the overall reduc- 
tion in clam numbers Singapore has experienced during the last few decades. The majority of neutrality tests (Tajima's $D$ and Fu's Fs) did not reject the null hypothesis of neutral evolution of COI for populations in Singapore (Table 2). Significant Tajima's $D$ for Tridacna squamosa reflects an excess of rare polymorphisms in the population, and these values indicate either positive selection (rejected by the mismatch analysis) or a recent population expansion (Tajima 1989, Fu 1997). Loss of habitats during low sea levels of the last glacial period (Bird et al. 2006) can result in population bottlenecks, whereas new habitats associated with sea level rise facilitate expansion of relict populations (Fauvelot et al. 2003). Similar signs of population expansions were found in T. crocea (DeBoer et al. 2008, Kochzius \& Nuryanto 2008) and T. maxima (Nuryanto \& Kochzius 2009) in the Indo-Malay Archipelago.

The qualitative results presented in Figs. 2 \& 3 suggest relatively higher levels of genetic diversity for Tridacna crocea than for T. squamosa. Genetic studies on $T$. crocea have shown strong population structure across the Indo-Malay Archipelago, indicating restricted gene flow between almost all the sample sites (DeBoer et al. 2008, Kochzius \& Nuryanto 2008). No similar studies exist for T. squamosa, but in Singapore, a single haplotype present in half of the individuals collected suggests gene flow and possibly panmixis (except Haplotype 16, which may have derived from a neighboring reef). Patterns of ocean currents affect the frequency of larval exchange (White et al. 2010) and T. squamosa populations may be connected due to the current regimes within the Straits of Singapore (Bird et al. 2006). If larvae, however, are simply being well dispersed among islands, the same degree of connectivity should also be seen in $T$. crocea. A single spawning event can explain the dominant haplotype in T. squamosa; for example, a pulse of genetically related larvae, potentially originating from beyond Singapore's waters, could have settled and persisted. If this population then matured with little or no additional input of genetic material from elsewhere, the outcome would be difficult to distinguish from panmixis. Alternatively, as T. crocea are usually found burrowed into rubble habitats (Hamner \& Jones 1976), while T. squamosa is freeliving (Rosewater 1965), human exploitation would be biased to removing the more easily harvestable $T$. squamosa, resulting in higher levels of genetic diversity in the less exploited species.

Even if there is some connectivity among Singapore's giant clams, the population may not be viable. Wada (1952) highlighted that, as the distance be- tween spawning adults increases, the likelihood of fertilization decreases rapidly (the Allee effect), and there is almost certainly a minimum population level at which no successful reproduction can take placeeven when adult clams are still present (Nash et al. 1988). Natural recruitment of giant clam larvae has been observed only in a few locations, including the Michaelmas Reef, central Great Barrier Reef (Braley \& Muir 1995) and Rose Atoll, Samoan Archipelago (Green \& Craig 1999). Rose Atoll has up to 225 Tridacna maxima ind. $\mathrm{m}^{-2}$ (Green \& Craig 1999) and is thought to have contributed to recruitment at nearby reefs. Other areas such as Palau (Hirschberger 1980); P. Tioman, Malaysia (Tan et al. 1998); Java, Indonesia (Brown \& Muskanofola 1985); and Lee-Pae Island, Thailand (Chantrapornsyl et al. 1996), support low giant clam densities of sparsely distributed mature adults, with few or no juveniles - a similar situation to Singapore. Even if the clams in Singapore did somehow manage to reproduce, the very low numbers and star-like parsimony networks (Viñas et al. 2004) indicate a population genetic bottleneck that reduces recovery.

Low giant clam densities coupled with Singapore's contemporary reef conditions, especially the lack of suitable substrate and reduced water quality (Burke et al. 2002), create a poor environment for reproduction and recruitment. It appears to be low mortality among the mature clams that maintains the present population (Yamaguchi 1977) but, with the adults exposed to ongoing stressors (Courtois de Vicose \& Chou 1999), Singapore's entire giant clam stock is endangered. Plans to restock these large and colourful bivalves in Singapore, through mariculture and subsequent out-planting, are underway. Larval dispersal models are being used to help identify nursery sites that have the greatest potential as sources of larvae for other Southern Island reefs. Improving water quality, however, continues to be the major challenge for local marine managers and substantial reductions in turbidity and sediment load will be required to ensure the successful conservation of giant clams in Singapore.

Acknowledgements. This research was conducted with a permit NP/RP961 from the National Parks Board, Singapore. We thank R. Tan and numerous volunteers for their time and effort during the clam surveys, T. DeBoer for her insights on giant clam genetics, R. Meier and S. Narayanan Kutty for laboratory space and assistance in molecular techniques, and J. Lai and D. Huang for help with the population genetics analyses. This study was supported by NParks CME grant number R-154-000-504-490. 


\section{LITERATURE CITED}

Arkema KK, Abramson SC, Dewsbury BM (2006) Marine ecosystem-based management: from characterization to implementation. Front Ecol Environ 4:525-532

Benzie JAH, Williams ST (1992a) Genetic structure of giant clam (Tridacna maxima) populations from reefs in the Western Coral Sea. Coral Reefs 11:135-141

Benzie JAH, Williams ST (1992b) No genetic differentiation of giant clam (Tridacna gigas) populations in the Great Barrier Reef, Australia. Mar Biol 113:373-377

Bird MI, Pang WC, Lambeck K (2006) The age and origin of the Straits of Singapore. Palaeogeogr Palaeoclim Palaeoecol 241:531-538

Braley RD, Muir F (1995) The case history of a large natural cohort of the giant clam Tridacna gigas (Fam. Tridacnidae) and the implications for re-stocking depauperate reefs with maricultured clams. Asian Fish Sci 8:229-237

Brown JH, Muskanofola MR (1985) An investigation of stocks of giant clams (family Tridacnidae) in Java and of their utilization and potential. Aquacult Fish Manag 1: 25-39

Burke L, Selig E, Spalding M (2002) Reefs at risk in Southeast Asia. World Resources Institute, Washington, DC

Carleton Ray G (1999) Coastal-marine protected areas: agonies of choice. Aquat Conserv 9:607-614

Carpenter KE, Barber PH, Crandall ED, Ablan-Lagman MCA and others (2011) Comparative phylogeography of the Coral Triangle and implications for marine management. J Mar Biol 2011:396982 doi:10.1155/2011/396982

Castelloe J, Templeton AR (1994) Root probabilities for intraspecific gene trees under Neutral Coalescent Theory. Mol Phylogenet Evol 3:102-113

Castilla JC (2000) Roles of experimental marine ecology in coastal management and conservation. J Exp Mar Biol Ecol 250:3-21

Chantrapornsyl S, Kittiwattanawong K, Adulyanukosol K (1996) Distribution and abundance of giant clams around Lee-Pae Islands, The Andaman Sea, Thailand. Phuket Mar Biol Center Spec Publ 16:195-200

Chou LM (1988) Community structure of sediment stressed reefs in Singapore. Galaxea 7:101-111

Chou LM (1999) Coral reefs. In: Briffett C, Chew HH (eds) State of the natural environment in Singapore. Nature Society, Singapore, p 33-45

Chou LM (2008) Chapter 10: nature and sustainability of the marine environment. In: Wong TC, Yuen B, Goldblum C (eds) Spatial planning for a sustainable Singapore. Springer Science, Dordrecht, p 169-182

Chou LM, Yu JY, Loh TL (2004) Impacts of sedimentation on soft-bottom benthic communities in the southern islands of Singapore. Hydrobiologia 515:91-106

> Clement M, Posada D, Crandall KA (2000) TCS: a computer program to estimate gene genealogies. Mol Ecol 9: $1657-1659$

Courtois de Vicose G, Chou LM (1999) Future of giant clam mariculture in Singapore: problems and potential solutions. Phuket Mar Biol Center Spec Publ 20:119-122

Crandall KA (1994) Intraspecific cladogram estimation: accuracy at higher levels of divergence. Syst Biol 43:222-235

> Crandall KA, Templeton AR (1993) Empirical tests of some predictions from coalescent theory with applications to intraspecific phylogeny reconstruction. Genetics 134: 959-969
Dawson RF, Philipson PW (1989) Chapter 6: the market for giant clam in Japan, Taiwan, Hong Kong and Singapore. In: Philipson DW (ed) The marketing of marine products from South Pacific. Institute of Pacific Studies of the University of the South Pacific, p 90-123

DeBoer TS, Subia MD, Ambariyanto, Erdmann MV, Kovitvongsa K, Barber PH (2008) Phylogeography and limited genetic connectivity in the endangered boring giant clam across the Coral Triangle. Conserv Biol 22:1255-1266

> Dikou A, van Woesik R (2006) Survival under chronic stress from sediment load: spatial pattern of hard coral communities in southern islands of Singapore. Mar Pollut Bull 52:1340-1354

Eliata A, Zahida F, Wibowo NJ, Panggabean LMG (2003) Abundance of giant clam in coral reef ecosystem at Pari Island: a population comparison of 2003's to 1984's data. Biota 8:149-152

Excoffier LGL, Schneider S (2005) Arlequin v3.0: an integrated software package for population genetics data analysis. Evol Bioinform Online 1:47-50

> Fauvelot C, Bernardi G, Planes S (2003) Reductions in the mitochondrial DNA diversity of coral reef fish provide evidence of population bottlenecks resulting from Holocene sea-level change. Evolution 57:1571-1583

Fu YX (1997) Statistical test of neutrality of mutations against population growth, hitchhiking and background selection. Genetics 147:915-925

Gomez ED, Mingoa-Licuanan SS, Roa-Quiaoit HA (2000) The culture of true giant clam Tridacna gigas for conservation in the Philippines. Mollusk Res Asia, p 159-163

Green A, Craig P (1999) Population size and structure of giant clams at Rose Atoll, an important refuge in the Samoan Archipelago. Coral Reefs 18:205-211

Grosberg RK, Cunningham CW (2001) Genetic structure in the sea: from populations to communities. In: Bertness MD, Gaines S, Hay ME (eds) Marine community ecology. Sinauer Associates, Sunderland, MA, p 61-84

Guest JR, Todd PA, Goh E, Sivalonganathan BS, Reddy KP (2008) Can giant clams (Tridacna squamosa) populations be restored in Singapore's heavily impacted coral reefs? Aquat Conserv 18:570-579

> Hamner WM, Jones MS (1976) Distribution, burrowing, and growth rates of the clam Tridacna crocea on intertior reef flats. Oecologia 24:207-227

> Harpending H (1994) Signature of ancient population growth in a low-resolution mitochondrial DNA mismatch distribution. Hum Biol 66:591-600

Harrison JL, Tham AK (1973) Chapter 14: the exploitation of animals. In: Chuang SH (ed) Animal life and nature in Singapore. Singapore University Press, Singapore, p 251-259

Hedgecock D (1986) Is gene flow from pelagic larval dispersal important in the adaptation and evolution of marine invertebrates? Bull Mar Sci 39:550-564

Hedgecock D, Barber PH, Edmands S (2007) Genetic approaches to measuring connectivity. Oceanography (Wash DC) 20:22-31

Hirschberger W (1980) Tridacnid clams stocks on Helen Reef, Palau, Western Caroline Islands. Mar Fish Rev 36:8-15

Huang D, Tun KPP, Chou LM, Todd PA (2009) An inventory of zooxanthellate scleractinian corals in Singapore, including 33 new records. Raffles B Zool Supp 22:69-80

Hviding E (1993) The rural context of giant clam mariculture 
in the Solomon Islands: an anthropological study. ICLARM, Manila

- Jantzen C, Wild C, El-Zibdah M, Roa-Quiaoit HA, Haacke C, Richter C (2008) Photosynthetic performance of giant clams, Tridacna maxima and T. squamosa, Red Sea. Mar Biol 155:211-221

Juinio-Meñez MA, Magsino RM, Ravago-Gotanco R, Yu ET (2003) Genetic structure of Linckia laevigata and Tridacna crocea populations in the Palawan shelf and shoal reefs. Mar Biol 142:717-726

Kilada R, Zakaria S, Farghalli ME (1998) Distribution and abundance of the giant clam Tridacna maxima (Bivalvia: Tridacnidae) in the Northern Sea. Bull Natl Inst Oceanog Fish ARE 24:221-240

Kochzius M, Nuryanto A (2008) Strong genetic population structure in the boring giant clam, Tridacna crocea, across the Indo-Malay Archipelago: implications related to evolutionary processes and connectivity. Mol Ecol 17: 3775-3787

Laurent V, Planes S, Salvat B (2002) High variability of genetic pattern in giant clam (Tridacna maxima) populations within French Polynesia. Biol J Linn Soc Lond 77: 221-231

Lee SK (1966) The natural history of the shore flora and fauna off Tanjong Teritip, Singapore. Malay Nat J 19: 259-274

Low JKY, Chou LM (1994) Sedimentation rates in Singapore waters. In: Sudara S, Wilkinson CR, Chou LM (eds) Proc 3rd ASEAN-Aus Symp Living Coast Resour, 16-20 May 1994, Chulalongkorn University, Bangkok. Vol 2: Res Pap. Australian Institute of Marine Science, Townsville, p 697-701

Lucas JS (1988) Giant clams: description, distribution and life history. In: Copland JW, Lucas JS (eds) Giant clams in Asia and the Pacific. Australian Centre for International Agricultural Research, Canberra, p 21-32

Luttikhuizen PC, Drent J, Baker AJ (2003) Disjunct distribution of highly diverged mitochondrial lineage clade and population subdivision in a marine bivalve with pelagic larval dispersal. Mol Ecol 12:2215-2229

Macaranas JM, Ablan CA, Pante MJR, Benzie JAH, Williams ST (1992) Genetic structure of giant clam (Tridacna deresa) populations from reefs in the Indo-Pacific. Mar Biol 113:231-238

McMichael DF (1974) Growth rate, population size and mantle coloration in the small giant clam Tridacna maxima (Röding), at One Tree Island, Capricorn Group, Queensland. Proc 2nd Intl Coral Reef Symp 1:241-254

Nash WJ, Pearson RG, Westmore WS (1988) Histological study on reproduction in the giant clams Tridacna gigas in the north central Great Barrier Reef. In: Copland JW, Lucas JS (eds) Giant clams in Asia and the Pacific. ACIAR Monogr 9, Canberra, p 89-94

$>$ Neo ML, Todd PA, Teo SLM, Chou LM (2009) Can artificial substrates enriched with crustose coralline algae enhance larval settlement and recruitment in fluted giant clam (Tridacna squamosa)? Hydrobiologia 625:83-90

Nuryanto A, Kochzius M (2009) Highly restricted gene flow and deep evolutionary lineages in the giant clam Tridacna maxima. Coral Reefs 28:607-619

Nuryanto A, Duryadi D, Soedharmaand D, Blohm D (2007) Molecular phylogeny of giant clams based on mitochondrial DNA cytochrome $c$ oxidase I gene. HAYATI J Biosci 14:162-166
Othman AS, Goh GHS, Todd PA (2010) The distribution and status of giant clams (family Tridacnidae): a short review. Raffles Bull Zool 58:103-111

Palumbi SR (2001) The ecology of marine protected areas. In: Bertness MD, Gaines SD, Hay ME (eds) Marine ecology: the new synthesis. Sinauer, Sunderland, MA, p 509-530

> Palumbi SR (2003) Population genetics, demographic connectivity, and the design of marine reserves. Ecol Appl 13:S146-S158

> Posada D, Crandall KA (2001) Intraspecific gene genealogies: trees grafting into networks. Trends Ecol Evol 16: 37-45

Purchon RD (1955) The structure and function of the British Pholadidae (rock-boring Lamellibranchia). Proc Zool Soc Lond 124:859-911

Rogers CS (1990) Responses of coral reefs and reef organisms to sedimentation. Mar Ecol Prog Ser 62:185-202

Rosewater J (1965) The family Tridacnidae in the IndoPacific. Indo-Pacific Mollusca 1:347-396

Scheltema R (1988) Initial evidence for the transport of teleplanic larvae of benthic invertebrates across the East Pacific Barrier. Biol Bull 174:145-152

Schneider S, Excoffier L (1999) Estimation of past demographic parameters from the distribution of pairwise differences when the mutation rates very among sites: application to human mitochondrial DNA. Genetics 152: 1079-1089

Selkoe KA, Henzler CM, Gaines SD (2008) Seascape genetics and the spatial ecology of marine populations. Fish Fish 9:363-377

Solis EP (1987) A preliminary study of the reproductive cycle of Tridacna squamosa Lamarck (Bivalvia: Tridacnidae) at Carbin Reef, Central Philippines. Silliman J 34:3-11

Tajima F (1989) Statistical method for testing neutral mutation hypothesis by DNA polymorphism. Genetics 123: 585-595

Tamura K, Dudley J, Nei M, Kumar S (2007) MEGA4: Molecular Evolutionary Genetics Analysis (MEGA) software version 4.0. Mol Biol Evol 24:1596-1599

Tan ASH, Yasin ZB (1998) The reproductive cycle of Tridacna squamosa and Tridacna maxima at Rengis Island (Tioman Island), Malaysia. Phuket Mar Biol Center Spec Publ 18:107-112

Tan ASH, Yasin ZB, Salleh IB, Yusof AA (1998) Status of giant clams in Pulau Tioman, Malaysia. Malay Nat J 52(3,4):205-216

> Templeton AR, Crandall KA, Sing CF (1992) A cladistic analysis of phenotypic associations with haplotypes inferred from restriction endonuclease mapping and DNA sequence data. III. Cladogram estimation. Genetics 132:619-633

Thia-Eng C, Gorre IRL, Ross SA, Bernad SR, Gervacio B, Ebarvia MC (2000) The Malacca Straits. Mar Pollut Bull 41:160-178

> Thompson JD, Gibson TJ, Plewniak F, Jeanmougin F, Higgins DG (1997) The CLUSTAL_X windows interface: flexible strategies for multiple sequence alignment aided by quality analysis tools. Nucleic Acids Res 25: 4876-4882

Todd PA, Ladle RJ, Lewin-Koh NJI, Chou LM (2004) Genotype $\times$ environment interactions in transplanted clones of the massive corals Favia speciosa and Diploastrea heliopora. Mar Ecol Prog Ser 271:167-182 
Todd PA, Lee JH, Chou LM (2009) Polymorphism and crypsis in the boring giant clam (Tridacna crocea): potential strategies against visual predators. Hydrobiologia 635: 37-43

> Viñas J, Bremer JA, Pla C (2004) Phylogeography of the Atlantic bonito (Sarda sarda) in the northern Mediterranean: the combined effects of historical vicariance, population expansion, secondary invasion, and isolation by distance. Mol Phylogenet Evol 33:32-42

Wada SK (1952) Protandric functional hermaphroditism in tridacnid clams. Oceanogr Mag (Tokyo) 4:23-30

White C, Selkoe KA, Watsons J, Siegel DA, Zacherl DC, Too-

Editorial responsibility: Christine Paetzold,

Oldendorf/Luhe, Germany nen RJ (2010) Ocean currents help explain genetic structure. Proc R Soc B Biol Sci 277:1685-1694

Wilkinson CR (ed) (2008) Status of coral reefs of the world: 2008. Global Coral Reef Monitoring Network and Reef and Rainforest Research Center. Australian Institute of Marine Science, Townsville

> Yamaguchi M (1977) Conservation and cultivation of giant clams in the Tropical Pacific. Biol Conserv 11:13-20

Yasin Z, Tan ASH (2000) Quantitative and qualitative effects of light on distribution of giant clams at the Johore islands in South China Sea. Phuket Mar Biol Center Spec Publ 21:113-118

Submitted: May 19, 2011; Accepted: December 2, 2011

Proofs received from author(s): February 24, 2012 